\title{
Optimal Mangrove Forest Management Based on Economic Value
}

\author{
Sri Arfiani ${ }^{1}$, Supratman $^{2}$, Muhammad Restu ${ }^{2}$ \\ ${ }^{I}$ Graduate Student of Forestry Science, Faculty of Forestry, Hasanuddin University, Indonesia \\ ${ }^{2}$ Lecturer, Faculty of Forestry, Hasanuddin University, Indonesia
}

\begin{abstract}
The activity of converting forest areas to non-forestry land uses has an impact on the decline in the function of forests as a buffer for sustainable development. The attempts to maintain the existence of forests need serious attention and need comprehensive, multi-sectoral handling, especially in the Mangrove Forest sector. The conversion of mangrove forest areas is caused by several factors, including community activities that convert forest areas into ponds. This study aimed to analyze the economic value of mangrove forests that are managed for tourism purposes and which have been converted into ponds and to analyze the economic value of mangrove forest management which is managed for the purpose of a combination of tourism ponds. The method used in this study was interview method with the community. The data obtained was then analyzed by using descriptive and quantitative analysis which was then calculated by using the method of calculating the total economic value (TEV). The results showed that there was a total economic value that was quite different between the two research locations, where in the mangrove forest area that had been converted into pond had a total economic value of 45,077,871/ha/year; while, in the mangrove forest area for tourism purposes, it had a total economic value of 45,077,871/ha/year. The total economic value is 85,381,115/ha/year. From the value of the two locations, the mangrove forest area for tourism purposes has a greater total economic value than the mangrove forest area that has been converted to pond due to some of the ecological functions of the mangrove forest that have been converted to pond land; while in the Mangrove forest area for tourism, it has added value in the form of economic value obtained from it. Therefore, to optimize the management of mangrove forests that have been converted into pond, a forest management scenario planning design is made with a combination between forest management method and the MMSSL management method (Mundur Selangkahuntuk Maju Sepuluh Langkah/Step Back for Ten Steps Forward)
\end{abstract}

Keywords-Mangrove Forest, Mangrove tourism, Mangrove conversion of ponds, Total economic value

\section{INTRODUCTION}

The activity of converting forest areas to non-forestry land uses can have an impact on the decline in the function of forests as a buffer for sustainable development, especially its function as a regulator of water management, prevention of floods and erosion and carbon sequestration. The attempts to maintain the existence of forests needs serious attention and need comprehensive multi-sectoral handling.

Forest, as one of the natural resources that is renewable, has a very essential role and contribution to the survival of mankind across generations. Therefore, it is highly important for the people of Indonesia to understand how much potential is contained in forest resources so that the process of managing and utilizing them in the context of economic, ecological, and social benefits will be carried out effectively and optimally.

Mangrove forest area is generally found throughout the coast of Indonesia and lives and grows in locations that have a tidal influence that inundates the flow of rivers along the coast. As a forest, mangrove forest is one of the coastal ecosystems that has distinctive characteristics. The physical functions of mangrove forests include: controlling the rising of the boundary between the ground water level and sea level towards the mainland, as a buffer zone, spurring land expansion and protecting the coastline to avoid erosion or abrasion [1].

The condition of the Mangrove Forest in South Sulawesi is currently quite severe, although it is not as bad as the condition of the mangrove forest in Jakarta. Based on data from the Forestry Office of South Sulawesi Province in 2014, the area of mangrove forests in South Sulawesi Province continues to decrease, mainly displaced by land clearing for ponds and settlements. With a beach length of approximately $1,937 \mathrm{~km}$ from west to east, the area of mangrove forest in South Sulawesi is only about 28,954.3 ha. From this area, only 5,238 ha is still in the good category, while the rest are in damaged and very damaged condition [2] 


\section{DOI: $10.51386 / 25815946 /$ ijsms-v4i6p111}

Especially for the district of Bangkala, regency of Jeneponto itself, it has a mangrove area that has decreased from 2012 with an area of $25.57 \mathrm{Ha}$ to $20.78 \mathrm{Ha}$ in 2017 (Depreciation of $4.79 \mathrm{Ha}$ ). This is due to the community's encouragement to minimize the economic crisis so that people are encouraged to open salt ponds. [3] The increasing demand for salt production and the scarcity of products at certain times are classic reasons for farmers to expand and clear land at the expense of mangrove forests.

Rehabilitation and conservation is one of the strategies in overcoming the damage to mangrove forests, by involving stakeholders such as the community, the government, the private sector, and other stakeholders. Efforts to involve and synergize from various parties can be carried out in the form of mangrove forest ecotourism management [4]. In order that realizing an expected mangrove forest as the educational tourism attraction, it needs systematic attempts that involve all parties to understand and put more attention on the roles and the functions of mangrove forest in human life. The strategy for developing ideal mangrove forests in the district of Tarowang as an educational tourism attraction is by utilizing the potential of the mangrove forest ecosystem so that it can become a source of community income [5]

Seeing the problems that occur from the results of research that has been carried out by Rizka in 2018, it can be concluded that the number of mangrove forest damage that occurred in South Sulawesi, especially in Jeneponto Regency, from 2012-2017 was increasing. The damage to the Mangrove Forest is largely influenced by the conversion of land functions from Mangrove Forest to Salt or Fish Pond Land. Thus, the economic value and environmental value of the Mangrove land is decreasing or even disappearing. When compared to the condition of the mangrove ecosystem in the district of Tarowang, where the mangrove forest area is managed or utilized for tourism purposes, to minimize the level of forest damage that will occur in the future at the location of the mangrove forest area that has been converted into pond land in the district of Bangkala and to optimize the management of the mangrove forest area so that it remains sustainable, a scenario design for mangrove forest management in combination with the Economic Value approach (TEV/Total Economic Value) method is made with a scenario design for mangrove forest management in combination with ponds and tourism.

\section{RESEARCH METHODS}

\section{A. Study Site}

This research was conducted in May -August 2021. This research was done in two locations, namely in a mangrove forest area with a tourist destination with a management area of 2 ha in BalangBaru Village, Tarowang District and in the mangrove forest area converted to ponds with an area of 20.78 ha in Pallengu Subdistrict, Bangkala District.

\section{B. Data Collection Technique}

The stages of this research activity begin with direct observation to the field or to the research location. The activities observed were in the form of utilization activities carried out by the surrounding community on the mangrove forest ecosystem. Furthermore, the interview process using a questionnaire was conducted after observing the location. Interviews were carried out with communities around forest areas. In addition to interviews with the community, in-depth interviews about the condition of mangrove forests were also conducted with several stakeholders who play an important role in the conservation and management of mangrove forest areas. In addition, a literature study was also performed through the collection of secondary data that supported this research. This research used descriptive and qualitative method. The population in this study was the community and fishermen as well as pond managers around the mangrove forest area who utilize the mangrove forest ecosystem. In this case, the sample used was purposive sampling technique where the determination of the sample was based on certain considerations with the consideration that the respondent had experience and had adequate information in meeting data needs.

\section{Data Analysis}

The data analysis used was descriptive and qualitative analysis. Descriptive analysis was used to describe the general condition of the location. In addition to the general condition of the location, this analysis was also used to describe what forms of management carried out by the community around the forest area in the natural utilization of the mangrove forest ecosystem in both locations. Furthermore, after the data have been obtained, it was then proceeded with a qualitative analysis by using the Economic Value method or the calculation of the total economic value of the two mangrove forest areas. For some benefits value, it was calculated by using the 


\section{DOI: $10.51386 / 25815946 /$ ijsms-v4i6p111}

market price approach which was converted into a value of Rp. Moreover, some other benefits that cannot be calculated at market prices or non-market prices were calculated by using the substitute method. From the total economic value obtained from the two areas, it will be known which forest area is more optimal by considering the economic value and the sustainability value of the mangrove forest area. Then, the last one is planning the strategic design of mangrove forest conservation.

\section{III.RESULTS AND DISCUSSION}

\section{A. Description of Mangrove Forest Area Management}

Mangrove forest management is an activity carried out by the community in terms of utilizing the mangrove ecosystem both within the mangrove forest area and around the area. This utilization is intended that there is value contained in the mangrove forest area that can be utilized by the community, whether it can be used directly or indirectly. The forms of the mangrove area management at the location of this research include:

\section{Description of Tourism Mangrove Area Management}

According to data from the Department of Fisheries and Maritime Affairs of Jeneponto Regency in 2020, the total area of mangrove forest in BalangBaru Village is 20 ha or about $65 \%$ of the total area of mangrove forest in Tarowang district. The total area of this mangrove area spreads from east to west. A small part or about 2 ha $(10 \%)$ of the mangrove forest area is managed by the community as a mangrove tourism area, namely kawasanwisata mangrove idaman (ideal mangrove tourism area).

The mangrove forest area in BalangBaru Village is also experiencing degradation due to conversion to pond land by the surrounding community. The increasing rate of forest degradation in this mangrove forest area has resulted in several pond areas that are directly adjacent to the coast to suffer damage such as pond leaks. From the damage to ponds that frequently occur every year, the community or pond owners have to pay some money to overcome these problems. This condition will result in huge losses for the owners of ponds, especially ponds that are directly adjacent to the beach and if not anticipated, it will continue to other ponds in it. In addition to the conversion of mangrove land into ponds, forest degradation also occurs due to community activities that utilize mangrove wood from mangroves as the main source for the community for firewood raw materials.

The major impact of mangrove forest degradation is the occurrence of floods that occur in community settlements as a result of the tsunami in Maumere. This finally made the people of BalangBaru Village aware to manage the mangrove forest area sustainably. One of the real measures taken by the community to no longer convert mangrove forests is to manage mangrove areas as tourist destination. The BalangBaru Village Government initiated the management of the tourism mangrove forest in 2017 by incorporating the program into the Village Medium-Term Development Plan (RPJMDes) in 2017 and inaugurated by the Regent of Jeneponto in 2018.

\section{Description of Pond-Converted Mangrove Area Management}

Mangrove Forest in Pallengu Village, Bangkala Regency has an area of 5 ha. This area is the remaining total area of mangrove forest that has been converted by the surrounding community into salt ponds and fish ponds areas. Since early 1991, the people of Pallengu Village have been starting converting mangrove land into ponds. This area conversion activity was carried out due to the increasing demand for salt production and the increase in sales of salt production from year to year. In addition, the main reason people convert mangrove land into ponds is because Jeneponto ponds are one of the ponds that are the main source of salt in Indonesia.

From the results of research [3] stating that the rate of damage to mangrove forests from 2012 to 2017, the shrinkage rate of the mangrove forest area is 4.79 ha, which was initially 25.57 ha in 2012 in 2017 the remaining 20.78 ha of the mangrove forest area. Meanwhile, according to the Department of Fisheries and Marine Affairs of Jeneponto Regency in 2020, the area of mangrove forest in Pallengu Sib-district, Bangkala District is only 5 ha left. The area of mangrove forest in Jeneponto Regency as follows: The condition of the mangrove forest in Bangkala District especially in Pallengu Sub-district experienced a drastic reduction in the total area, where from the results of research [3] the area of mangrove forest was 20.78 ha to 5 ha in 2020 . The rate of forest degradation that occurred within 3 years was 15.78 ha. 


\section{DOI: $10.51386 / 25815946 /$ ijsms-v4i6p111}

Volume: 4 Issue: 6

November to December 2021

https://www.ijsmsjournal.org

\section{B. Economic Value of Mangrove Forest}

Identification of the benefits and functions of the mangrove ecosystem in BalangBaru Village as a tourism mangrove forest area and in Pallengu Sub-district as a mangrove forest area for pond conversion is grouped into four categories, namely direct benefits, indirect benefits, optional benefits, and existence benefits.

\section{Economic Value of Tourism Mangrove}

\section{Direct Benefit}

Based on the results of identification and field studies, the direct benefits of the mangrove ecosystem in Tarowang District that can be directly perceived are catching marine products around the mangrove forest area in the form of catching crabs and shrimp. The results of interviews from respondents who work as fishermen stated that for shrimp and crabs to be caught around the forest area, while for fish, local fishermen had to go out to the open sea to be able to catch and produce them on a large scale so that the value of the benefits obtained from the mangrove forest area here is only shrimp and crab.

Based on the analysis results on the value of direct benefits from the mangrove forest area which is then qualified into the value of money or Rp. Based on the market price, the total value of the direct benefits of using the mangrove ecosystem in BalangBaru Village is Rp. 1,872,990,000/year or Rp. 935.005.000/ha/year. For more detail, it is presented in the table below:

Table 1. Value of direct benefits

\begin{tabular}{|c|c|c|c|}
\hline No & Type of Benefits & $\begin{array}{c}\text { Total Amount/year } \\
(\mathbf{R p})\end{array}$ & Total Amount/ha/year (Rp) \\
\hline $\mathbf{1}$ & Seed potential value & $\mathbf{4 6 6 . 0 1 0 . 0 0 0}$ & $\mathbf{2 3 3 . 0 0 5 . 0 0 0}$ \\
\hline $\mathbf{2}$ & Fish value & $\mathbf{2 1 . 6 0 0 . 0 0 0}$ & $\mathbf{1 0 . 8 0 0 . 0 0 0}$ \\
\hline 3 & Shrimp value & 50.400 .000 & 25.200 .000 \\
\hline 4 & Crab Value & 89.280 .000 & 43.200 .000 \\
\hline 5 & Tourism Value & 36.000 .000 & 18.000 .000 \\
\hline 6 & Fishpond Value & 1.209 .700 .000 & 604.850 .000 \\
\hline & Total & 1.872 .990 .000 & $\mathbf{9 3 5 . 0 0 5 . 0 0 0}$ \\
\hline
\end{tabular}

Source: Primary data after processing, 2021

\section{Indirect Benefit Value}

Indirect benefit from the mangrove forest ecosystem of Tarowang Regency is in a physical form. This physical benefit is in the form of the benefit of the mangrove ecosystem as a land protector from the threat of abrasion and flooding caused by high tides or waves from the sea. In addition, the physical benefit of the mangrove forest area is in the form of absorption of $\mathrm{Co} 2$. The indirect benefit value in the form of a physical form is in the form of a breakwater building or a wave barrier in which its measurement value is calculated based on the market value with the approach of making a breakwater building [6]

Based on the interview results that have been conducted with an employee or staff at the Department of Public Works (PU) in the irrigation facilities and infrastructure section, it is stated that for the construction of a breakwater building with a size of $1 \mathrm{~m}$ high, 2 meters wide and 1 meter thick, cost of Rp. 869,000 is needed. The breakwater building is assumed to last for 10 years with the type of building in the form of Gabion. The elaboration of the total cost, namely for building materials for the breakwater, the gabion wire itself is Rp. 136,000 , then the price of materials used is 436,000 and labor cost is Rp. 295,000 .

From the total cost of the breakwater building that has been obtained, the total cost that must be used to make a breakwater building with a coastline length of $849 \mathrm{~m}$ with an area of 2 ha is Rp. 737,781,000 assuming the durability of the building for 10 years, it takes about Rp. 73,778,100/year. Thus, the value of indirect benefits from the mangrove ecosystem in Tarowang District is Rp. 73,778,100/year or Rp. 86,900/meter/year. Meanwhile, for the indirect benefits resulting from the physical function as a $\mathrm{CO} 2$ absorber, it is Rp. 4,158,560/year or Rp. 2,079,280/ha/year. 


\section{DOI: $10.51386 / 25815946 /$ ijsms-v4i6p111}

\section{Optional Benefit Value}

The optional benefits of mangrove ecosystems in Tarowang District are calculated from the benefits of biodiversity. According to Ruitenbeek [7] in [6], the value of biodiversity in Indonesia is US $\$ 1,500 / \mathrm{km} 2 / \mathrm{year}$ with the exchange rate of the Rupiah on the dollar of Rp. 14,271 (October 2021). Based on the value of biodiversity, for the area of mangrove land, Tarowang District of 2 ha will result in the value of the optional benefit of Rp. 214,065/ha/year or Rp. 428,130/year.

\section{Existence Benefit Value}

Existence benefit is a value that indicates a person's willingness to pay for a service to preserve the mangrove ecosystem for future use. The value of this benefit is obtained from the CVM (Contingent Valuation Method) equation. The level of importance of the mangrove ecosystem in Tarowang District is presented in the following table.

Table 2. The existence value of the mangrove ecosystem

\begin{tabular}{|c|c|c|c|}
\hline No & The Importance of Mangrove & Not Fisherman & Fisherman \\
\hline 1 & Important & 7 & 12 \\
\hline 2 & Unimportant & 0 & 0 \\
\hline 3 & Average & 3 & $\mathbf{8}$ \\
\hline
\end{tabular}

Source: Primary data after processing, 2021

Based on the table above, it can be stated that only a small number of people think that the mangrove ecosystem is normal, in fact there are no respondents who states that the mangrove ecosystem is not important. In reality, most of the respondents stated that the mangrove ecosystem is important.

Table 3. Availability of respondents to pay for mangrove ecosystem services

\begin{tabular}{|c|c|c|c|c|}
\hline No & Amount & $\begin{array}{c}\text { Number of } \\
\text { people }\end{array}$ & \% & Total (Rp) \\
\hline 1 & 50.000 & 11 & $36.67 \%$ & 550.000 \\
\hline 2 & 75.000 & 14 & $46.67 \%$ & 1.050 .000 \\
\hline 3 & 100.000 & 5 & $16,66 \%$ & 500.000 \\
\hline & Total amount & $\mathbf{3 0}$ & $\mathbf{1 0 0}$ & $\mathbf{2 . 1 0 0 . 0 0 0}$ \\
\hline
\end{tabular}

Source: Primary data after processing, 2021

The table above describes WTP of respondents who have been interviewed in the field with the majority of their jobs being fishermen. The availability of respondents to pay wages or services for the mangrove ecosystem is tremendously high. There are about 14 respondents or about $46.67 \%$ who are willing to pay Rp. 75,000 ; while respondents who are willing to pay Rp. 50,000 by 11 respondents or about $36.67 \%$.

Existence benefits of the mangrove forest area in Tarowang District is calculated by using the CVM approach method with the average value obtained from 30 respondents, namely Rp. 80,833/person with a population of 923 people in BalangBaru Village, the total value of the benefits of being in BalangBaru Village is Rp. 74,608,859/year or Rp. 37,304,429/ha/year.

\section{Economic Value of Pond-converted Mangrove Ponds}

\section{Direct benefit value}

Based on the results of identification and field studies, the direct benefits of the mangrove ecosystem in Pallengu Sub-district that can be directly benefited is the capture of marine products around the mangrove forest area in the form of catching fish, crab, and shrimp. Based on the analysis results of the value of direct benefits from the mangrove forest area which is then qualified into the value of money or Rp. Based on the market price, the value of Rp. 462,939,200/year or Rp. 92,587,840/ha/year. For more detail, it can be seen from the table below: 
DOI: $10.51386 / 25815946 /$ ijsms-v4i6p111

Volume: 4 Issue: 6

November to December 2021

https://www.ijsmsjournal.org

Table 4. Direct benefit value of Mangrove in Bangkala District

\begin{tabular}{|c|c|c|c|}
\hline No & Type of Benefits & Total Amount/year (Rp) & Total Amount/ha/year (Rp) \\
\hline 1 & Fish & 5.400 .000 & 1.080 .000 \\
\hline 2 & Shrimp & 31.200 .000 & 6.240 .000 \\
\hline 3 & Crab & 426.339 .200 & 85.267 .840 \\
\hline 4 & Fishpond & 9.860 .700 .000 & 497.261 .724 \\
\hline 5 & Salt Pond & 602.038 .800 & 3.036 .000 \\
\hline & Total & $\mathbf{1 0 . 9 2 5 . 6 7 8 . 0 0 0}$ & $\mathbf{5 9 2 . 8 8 5 . 5 6 4}$ \\
\hline
\end{tabular}

Source: Primary data after processing, 2021

\section{Indirect Benefit Value}

Indirect benefit from the mangrove forest ecosystem in Pallengu Sub-district is in the form of physical benefits from a mangrove ecosystem which include preventing abrasion or flooding, absorbing $\mathrm{Co} 2$ and protecting against pond leakage. [6]. Based on the results of interviews that have been conducted with an employee or staff at the Department of Public Works (PU) in the irrigation facilities and infrastructure section, it is stated that for the construction of a breakwater building with a size of $1 \mathrm{~m}$ high, 2 meters wide and 1 meter thick, the cost is Rp. Rp. 869,000. The breakwater building is assumed to last for 10 years with the type of building in the form of Gabion. The elaboration of the total cost, namely for building materials for the breakwater, the gabion wire itself is Rp. 136,000, then the price of materials used is 436,000 and labor cost is Rp. 295,000.

From the total cost of the breakwater building that has been obtained, the total cost that must be used to make a breakwater building with a coastline length of 8,821 m with an area of 5 ha is Rp. 7,665.449,000 assuming the durability of the building for 10 years, it takes approximately Rp. 766,544,900/year. Hence, the value of indirect benefits from the mangrove ecosystem in Pallengu sub-district is Rp. 766,544,900/year or Rp. $153,308,980$.

In addition to the indirect benefit value from the benefits of the mangrove ecosystem as a flood, there is also an indirect benefit value from CO2 absorption of Rp. 43,207,439/year or Rp. 8,641,488/ha/year and the direct benefit value from protection against pond leakage is Rp. 19,166,665/year or Rp. 3,833,333/ha/year. Therefore, the total indirect benefit value of the mangrove forest ecosystem in Pallengu Sub-district is Rp. $828,919,003 /$ year or Rp. 165,783,801/ha/year.

\section{Optional benefit value}

The optional benefits of mangrove ecosystems in Bangkala District are calculated from the benefits of biodiversity. According to Ruitenbeek [7] in [6], the value of biodiversity in Indonesia is US \$1,500/km2/year with the exchange rate of the rupiah against the dollar of Rp. 14,271 (October 2021). Based on the value of biodiversity, for the area of mangrove land, Bangkala District of 20.78 ha will result in an optional benefit value of Rp. 1.070.325/year or Rp. 214,064/ha/year.

\section{Existence benefit value}

Existence benefit is a value that indicates a person's willingness to pay for a service to preserve the mangrove ecosystem for future use. The value of this benefit is obtained from the CVM (Contingent Valuation Method) equation. The level of importance of the mangrove ecosystem in Tarowang District is presented in the following table.

Table 5. Existence value of mangrove ecosystems

\begin{tabular}{|c|c|c|c|}
\hline No & The Importance of Mangrove & Not Fisherman & Fisherman \\
\hline 1 & Important & 8 & 15 \\
\hline 2 & Unimportant & 0 & 0 \\
\hline 3 & Average & 2 & $\mathbf{5}$ \\
\hline
\end{tabular}

Source: Primary data after processing, 2021 
DOI: $\underline{10.51386 / 25815946 / \mathrm{ijsms}-\mathrm{V} 4 \mathrm{i} 6 \mathrm{p} 111}$

Volume: 4 Issue: 6

November to December 2021

https://www.ijsmsjournal.org

Based on the table above, it can be stated that only a small number of people think that the mangrove ecosystem is normal, in fact there are no respondents who states that the mangrove ecosystem is not important. In reality, most of the respondents claimed that the mangrove ecosystem is important.

Table 6. Availability of respondents to pay for mangrove ecosystem services

\begin{tabular}{|c|c|c|c|c|}
\hline No & Amount & $\begin{array}{c}\text { Number of } \\
\text { People }\end{array}$ & \% & Total (Rp) \\
\hline 1 & 50.000 & 7 & $23,33 \%$ & 350.000 \\
\hline 2 & 75.000 & 9 & $30 \%$ & 675.000 \\
\hline 3 & 100.000 & 14 & $46.67 \%$ & 1.400 .000 \\
\hline & Total Amount & $\mathbf{3 0}$ & $\mathbf{1 0 0}$ & $\mathbf{2 . 4 2 5 . 0 0 0}$ \\
\hline
\end{tabular}

Source: Primary data after processing

The table above describes WTP of respondents who have been interviewed in the field with the majority of their jobs being fishermen. The availability of respondents to pay wages or services for the mangrove ecosystem is tremendously high. There are about 14 respondents or about $46.67 \%$ who are willing to pay Rp. 100,000; while respondents who are willing to pay Rp. 50,000 by 7 respondents or about $23.33 \%$.

Existence benefit or existence value of the mangrove forest area in Pallengu Sub-district is calculated by using the CVM approach method with the average value obtained from 30 respondents, which is Rp. $80,833 /$ person with a population of 630 people, the value of the existence benefits of the mangrove ecosystem in Pallengu Sub-district is Rp. 50,924,790/year or Rp. 10,184,958/ha/year.

\section{Total Economic Value of Tourism Mangrove Ecosystem}

Table 7. Total economic value of tourism mangroves

\begin{tabular}{|l|l|r|r|r|}
\hline No & \multicolumn{1}{|c|}{ Type of Benefits } & $\begin{array}{r}\text { Total Economic } \\
\text { Value (Rp/year) }\end{array}$ & $\%$ & \multicolumn{1}{|c|}{$\begin{array}{c}\text { Economic Value } \\
\text { (Rp/ha/year) }\end{array}$} \\
\hline 1 & Direct benefit value & & \\
& Seed Potential Value & 466.010 .000 & 23,00 & 233.005 .000 \\
& Fisheries Value & & \\
& $\checkmark \quad$ Fish Value & 21.600 .000 & 1,07 & 10.800 .000 \\
& $\checkmark \quad$ Shrimp Value & 50.400 .000 & 2,49 & 25.200 .000 \\
& $\checkmark \quad$ Crab Value & 89.280 .000 & 4,41 & 44.640 .000 \\
& Tourism Value & 36.000 .000 & 1,78 & 18.000 .000 \\
& Fishpond Value & 1.209 .700 .000 & 59.71 & 57.880 .383 \\
\hline & Total Direct Benefit Value & $\mathbf{1 . 8 7 2 . 9 9 0 . 0 0 0}$ & $\mathbf{9 2 , 4 5}$ & $\mathbf{3 8 9 . 5 2 5 . 3 8 3}$ \\
\hline 2 & Indirect Benefit Value & 4.158 .560 & 0,21 & 2.079 .280 \\
& CO2 Absorption Value & 73.778 .100 & 3,64 & 36.889 .050 \\
& Protection Value agains Ponds & & & \\
\hline & (Abrasion) & $\mathbf{7 7 . 9 3 6 . 6 6 0}$ & $\mathbf{3 , 8 5}$ & $\mathbf{3 8 . 9 6 8 . 3 3 0}$ \\
\hline & Total Indirect Benefit Value & $\mathbf{4 2 8 . 1 3 0}$ & $\mathbf{0 , 0 2}$ & $\mathbf{2 1 4 . 0 6 5}$ \\
\hline 3 & Optional Benefit Value & $\mathbf{7 4 . 6 0 8 . 8 5 9}$ & $\mathbf{3 , 6 8}$ & $\mathbf{3 7 . 3 0 4 . 4 3 0}$ \\
\hline 4 & Existence Benefit Value & $\mathbf{2 . 0 2 5 . 9 6 3 . 6 4 9}$ & $\mathbf{1 0 0}$ & $\mathbf{4 6 6 . 0 1 2 . 2 0 7}$ \\
\hline & Total Economic Value & &
\end{tabular}

Source: Primary data after processing, 2021

From the results of identification obtained from the mangrove ecosystem in BalangBaru Village, there are several benefit values including direct benefits, indirect benefits, optional benefits, and existence benefits which are quantified into rupiah values, so the total economic value of mangroves is Rp. 466.021,207/ha/year or Rp. $2,025,963,649 /$ year.

The direct benefit value is the largest contributor to the total value of benefits from the mangrove ecosystem, which is Rp. 1,872,990,000/year or $92.45 \%$ of the total value as a whole, while the optional benefit value is the 
DOI: $10.51386 / 25815946 /$ ijsms-v4i6p111

Volume: 4 Issue: 6

November to December 2021

https://www.ijsmsjournal.org

smallest contributor to the total economic value of mangroves in BalangBaru Village which is only about $0.02 \%$ or about Rp. 428,130/year.

The total economic value of the mangrove ecosystem in BalangBaru Village is quite large. Several factors that support the total economic value of the mangrove ecosystem in BalangBaru Village are caused by several forms of community activity, namely the use of mangrove areas as tourist areas. In addition, around the mangrove area, there are several community ponds that also contribute to the direct benefit value of the mangrove ecosystem in BalangBaru Village.

\section{Total Economic Value of Pond-Conversion Mangrove Ecosystem}

Table 8. Total economic value of pond-converted mangrove

\begin{tabular}{|c|c|c|c|c|}
\hline No & Type of Benefits & $\begin{array}{l}\text { Total Economic } \\
\text { Value (Rp/year) }\end{array}$ & $\%$ & $\begin{array}{c}\text { Economic Value } \\
\text { (Rp/ha/year) }\end{array}$ \\
\hline 1 & 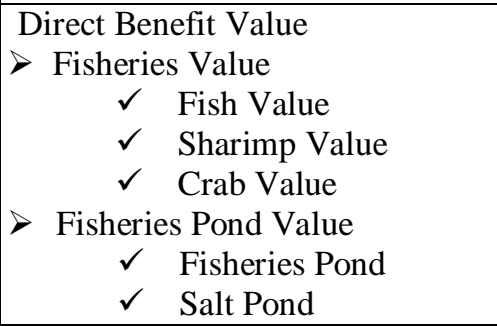 & $\begin{array}{r}5.400 .000 \\
31.200 .000 \\
426.339 .200 \\
\\
9.860 .700 .000 \\
315.392 .623 \\
\end{array}$ & $\begin{array}{c}0,05 \\
0,26 \\
3,61 \\
83,52 \\
5,10 \\
\end{array}$ & $\begin{array}{r}1.080 .000 \\
6.240 .000 \\
85.267 .840 \\
\\
49.726 .172 \\
4.023 .920 \\
\end{array}$ \\
\hline & Total Direct Benefit Value & 10.639.031.823 & 92,54 & 146.337.932 \\
\hline 2 & $\begin{array}{l}\text { Indirect Benefit Value } \\
\text { CO2 Absorption Value } \\
\text { Protection Value against Ponds } \\
\text { (abrasion) } \\
\text { Protection Value against Pond } \\
\text { Leaks }\end{array}$ & $\begin{array}{r}43.207 .438 \\
766.544 .900 \\
19.166 .665\end{array}$ & $\begin{array}{l}0,37 \\
6,49 \\
0,16\end{array}$ & $\begin{array}{r}8.641 .488 \\
153.308 .980 \\
\\
3.833 .333\end{array}$ \\
\hline & Total Indirect Benefit Value & 828.919.003 & 7,01 & 165.783 .801 \\
\hline 3 & Optional Benefit Value & 1.070 .325 & $\mathbf{0 , 0 1}$ & 214.065 \\
\hline 4 & Existence Benefit Value & 50.924 .790 & $\mathbf{0 , 4 3}$ & 10.184 .958 \\
\hline & Total Economic Value & 11.519.945.941 & 100 & 322.520.756 \\
\hline
\end{tabular}

Source: Primary data after processing, 2021

Table 8 above shows that the total economic value of mangrove forest in Pallengu Sub-district is Rp. $11,519,945,941 /$ year or around 322,520,756/ha/year. From the four existing benefit values, namely the value of direct benefits, the value of indirect benefits, the value of optional benefits, and the value of the existence benefits, the value of direct benefits is the largest contributor to the value of Rp. 10,638,031,823/year (92.54\%) or Rp. 146,337,932/ha/year. Meanwhile, the smallest value contributor is the optional value, which is only Rp. $1,070,325 /$ year $(0.01 \%)$.

The total economic value of the mangrove ecosystem that has been converted into pond land in Pallengu Sub-district is quite small with a total area of 5 ha of mangrove forest only having a total economic value of Rp. $322,520,756 /$ ha/year or Rp. 11,519,945,941/year. The total economic value of the mangrove forest area in Pallengu Sub-distrct is considered very small because some forms of community activity in terms of utilizing the mangrove ecosystem are no longer effective so that the value of the income generated is also starting to decrease. In addition, the community around the mangrove forest area does not focus on the utilization of the mangrove ecosystem but focuses more on the management and utilization of fishery ponds and salt ponds around the mangrove forest area in Pallengu Sub-district.

\section{Scenario Planning for Management of Mangrove Forest Areas for Tourism Pond Conversion}

Based on the data from the analysis of the forms of utilization of the mangrove area which is managed as a tourist area in BalangBaru Village and the mangrove area that has been converted to a pond in Pallengu Subdistrict, then for the plan for the management of the mangrove forest area in Pallengu Sub-district will be 


\section{DOI: $\underline{10.51386 / 25815946 / i j s m s-v 4 i 6 p 111}$}

managed by combining the conversion mangrove area of the pond and the tourism mangrove area. This form of combined mangrove area management aims to rehabilitate mangrove forest areas that have been damaged into areas that have additional economic value from the tourism. The form of the management plan uses the "MSMSL" MundurSelangkahMajuSepuluhLangkah(Step Back for Ten Steps Forward)model. The "MSMSL" strategy or planning model is one of the strategies that in general can experience changes following the conditions around the mangrove forest area. This change includes the level of success and the form of the management model that will be used later. In line with [8] stating that a strategy can change due to changes in the internal and external conditions of an area.

The MSMSL model is one of the mangrove area management models that uses pond areas as land for mangrove rehabilitation. The mechanism for this MSMSL management method is to carry out forest rehabilitation in the community pond area around the mangrove area. The area planted with mangrove seedlings is $1 \mathrm{~m}$ from the embankment into the pond area. This rehabilitation process is assumed to be successful within 10 years so that this mangrove rehabilitation area will minimize the costs incurred by the community who own ponds for pond maintenance costs and repairs from leaks caused by sea waves.

\section{CONCLUSIONS}

\section{BASED ON THE RESEARCH RESULTS AND DISCUSSION, SEVERAL CONCLUSIONS CAN BE MADE, NAMELY:}

1. The total economic value of the mangrove forest area with an area of 2 ha and managed as a tourism mangrove forest area in BalangBaru Village is Rp. 466,012,207/ha or around Rp. 2,025,963,649/year. This total economic value is obtained from several benefits such as the direct benefit value of $\mathrm{Rp}$. $389,525,383 /$ ha or Rp. 1,872,990,000/year (92.45\%), the indirect benefit value of Rp. 77,936,660/year (3.85\%) or Rp. 38,968,330/ha, the optional benefit value of Rp. 428,130/year (0.02\%) or Rp. 214,065 and the existence benefit value of Rp. 74,608,859/year (3.68\%) or Rp. 37,304,430/ha.

2. The total economic value of the mangrove forest area with an area of 5 ha and managed as a mangrove forest area that has been converted into fish and salt ponds in Pallengu Sub-district is Rp. 322,520,756/ha or around Rp. 11,519,945,941/year. This total economic value is obtained from several benefits such as the direct benefit value of Rp. 146,337,932/ha or Rp. 10,639,031,823/year (92.35\%), the indirect benefit value is Rp. 828,919,003/year (7.20\%) or Rp. 165,783,801/ha, the optional benefit value of $\mathrm{Rp}$. $1.070 .325 /$ year $(0.01 \%)$ or Rp. 214,065 and the existence benefit value of Rp. 50,924,790/year $(0.44 \%)$ or Rp. $10,184,958 /$ ha.

3. The planning strategy or scenario for the optimal management of mangrove forest areas is the management of the mangrove forest area in Pallengu Sub-district is used as a mangrove forest area, a combination of mangroves that have been converted into ponds and tourism mangroves using the "MSLMS" method.

\section{REFERENCES}

[1] Kustanti, A. 2011. ManajemenHutan Mangrove. Universitas Lampung Kabupaten Lampung Timur. Universitas Lampung. Bandar Lampung

[2] Tubagus, A. LP. 2020. PartisipasiMasyarakatDalamMembangunEkowisata Mangrove di DesaBalangBaruKab. Jeneponto. UniversitasHasanuddin Makassar.

[3] Amalia. Rizka. 2018. StudiDinamikaTutupanLahan Mangrove di SekitarLahanTambak di Kec. BangkalaKab. Jeneponto. UniversitasHasanuddin Makassar.

[4] Sungkawa, Q. T. 2015. PengembanganPotensiHutan Mangrove untuTujuanEkowisata di DesaMuaraKec. TeluknagaKab. Tanggerang. InstitutPertanian Bogor.

[5] Rijal, Samsul. 2020. PotensiHutan Mangrove Sebagai Daya Tarik Wisata (StudiKasusPadaHutan Mangrove IdamanKe. TarowangKab. Jeneponto Prov. Sulawesi Selatan). Journal of Tourism, Hospitality, Travel and Busines Event. Vol. 2 No. 2.

[6] Rospita, J. Z. 2017. ValuasiEkonomiEkosistem Mangrove di DesaPasarNgalamKabupatenSeluma. JurnalEnggano Vol. 2 No 1

[7] Ruitenbeek, H.J. 1991. Mangrove Management In Economic Analysis of Management Options with A Focus of Bintuni Bay Irian Jaya. EnviromentalManegement Development in Indonesia Project (EMDI). EMDI Enviromental Report No. 8. Jakarta.

[8] Ningsih, A. S., BaharuddindanMalammassam, D. 2021. Candlenut Business Development Strategy (Aleuritesmollucana L. Wild) in KPHL Selayar. International Jpurnal of Science and Management Studies (IJSMS) 4(3), 224-234 